УДК 378.016:811.111:784.6

DOI: https://doi.org/10.35619/iiu.v0i9.12

Svitlana Romaniuk

$\mathrm{PhD}$ in Philology, Associate Professor, Associate Professor at the Foreign Languages Department, Rivne State University of the Humanities

Rivne, Ukraine

ORCID: 0000-0002-9355-4584,

e-mail: sve-romanyuk@ukr.net

\title{
LEARNING ENGLISH THROUGH SONGS AS ONE OF INNOVATIVE METHODS OF EDUCATION
}

\begin{abstract}
The article deals with the peculiarities of the introduction of the method of learning English songs in the process of teaching "English for Specific Purposes" for students of "Music" specialty at higher education institutions. The author considers the essence and features of this innovative method, analyzes its main principles and priorities. In particular, the stages of work with a song composition and examples of exercises on the acquisition of language material are considered. The article substantiates the methodical expediency of using the method of learning English songs in the process of teaching English in artistic specialties.

Recently, the higher educational institutions intensify the process of learning foreign languages through the introduction of the variety of teaching technologies. The method of learning English songs by students of "Music" specialty in English classes is efficient and productive, because of enriching the vocabulary, improving the pronunciation and grammar. The listening to song is used in the teaching process as an auxiliary tool for students to learn new linguistic material in its sound expression. It increases the efficiency of students' professional training. Poetic and song material encourages creativity, performing verse translations, composing poetry and songs in native and English languages, promotes the memorization of new words due to the rhymed forms as a great way of phonetic training. It is proved that proposed method of learning English through songs provides a positive pedagogical effect and shows the prospects of combining innovation with traditional teaching methods. Therefore, our further task is the development of educational and teaching materials in the proposed aspect and their implementation in higher education institutions, because it allows a future specialist to acquire professional skills through the modeling the subject content of the future profession.
\end{abstract} specialties.

Key words: teaching English, innovative method, studying songs, artistic

Formulation of the problem. In the conditions of the growth of the integration of education, science and production, the task of preparing and forming the creative specialist, the gradual transformation of the student's educational activity into professional one is of great importance.

Under the terms of the Bologna Declaration, the restructuring of the national system of higher education takes place. Its content changes and the sphere of its actualization extends, which requires improvement of the organization of teaching a foreign language at the higher educational establishment. Priority role belongs to 
interactive methods and innovative learning technologies, which stimulates creativity, initiative, independent and critical thinking in students.

One of the most unusual and relevant approaches to studying English by students of artistic specialties is using of the method of learning English songs. Since the goal of teaching a foreign language is not only the acquisition of knowledge and the formation of skills and abilities of students, but also the comprehensive assimilation of their knowledge of linguistic, ethno-cultural and aesthetic nature, knowledge of the values of another nation through samples of song creativity.

Analysis of recent research on the problem. Methodologists have been working out the problems of using poetry texts, songs and music in the lessons of foreign language for several decades. The effectiveness of using songs in English lessons is analyzed by I. Ilchishin, O. Metolkina, O. Mikhailova, O. Nekrutenko, O. Stom, D. Eken, T. Dale and others. The role of music in improving memorization is the subject of research by such scholars as L. Asher, P. Vener, J. Evans, D. Schuster, M. Glazner.

The aim of the article. The purpose of the study is to investigate the method of learning English through songs as one of the ways to increase the efficiency of students' professional training in the specialty of "Music" in the process of learning English.

Presenting the main research material. Since the number of hours allocated to the curriculum on the discipline of "Foreign language for Specific Purposes" is limited, one of the teacher's tasks is using of methods that would yield the desired results in a short time. The question arises about the intensification of learning through the search and introduction of interesting technologies for the organization of students' educational activities.

Over the course of many years of teaching, we came to the conclusion that it is expedient to introduce the popular English songs into the learning process (Haponova, 2005; Holubev and Smirnova, 2003). It contributes to:

- expansion of the vocabulary, development of a sense of language, fixation of correct articulation and pronunciation of sounds;

- stimulation of monologue and dialogical speech and the development of both prepared and spontaneous speech;

- better learning and acquiring grammatical constructions used in English;

- development of socio-cultural competence;

- revitalizing the process of teaching, introducing diversity, positive emotions and creating high motivation;

- enriching the imagination, reducing the psychological burden of students and increasing their emotional tone (Zharska, 2006).

This form of work is especially relevant for faculties of artistic specialties, in particular, the specialty of "Music," which helps future musicians to improve their professional competence.

The song for learning is chosen, depending on the goal. It should be melodic, accessible and easy to remember. The listening to song is used by us as an auxiliary tool for students to learn new linguistic material in its sound expression (to show its meaning, form, and cases of use).

On the first practical class with students we aim to overcome the barrier of tension, distrust, shyness, and create a friendly atmosphere so that the students at the end of a practical class come out smiling and chanting the melody of the song. 
In the method of learning English through songs we distinguish the following stages (Petko, 2011):

- presentation of the song: the teacher explains the purpose for which the proposed song will be learned, tells about the history of writing the song (by whom and when it was performed);

- reading the lyrics: students read the lyrics silently in order to get acquainted and get the first impression;

- phonetic processing of the text: the teacher draws attention to the correct pronunciation of words and phonetic workout of individual sounds;

- reading and translating the lyrics by students: attention is paid to phraseological translations and grammatical structures;

- learning song: working out clear articulation, rhythm and melody;

- you can suggest listening to a song, singing whispering. After the first listening to the song, the teacher draws students' attention to those points that need attention, works out them again;

- $\quad$ performance of the song;

- doing lexical and grammatical exercises on the assimilation of the linguistic material of the song;

- homework: students are encouraged to make an artistic translation of the song in order to conduct a competition for the best translation on the next lesson.

We offer an example of studying the lyric song "Happy New Year!", which is positively perceived by students.

\section{HAPPY NEW YEAR!}

1 No more champagne

And the fireworks are through

Here we are, me and you

Feeling lost and feeling blue

It's the end of the party

And the morning seems so grey

So unlike yesterday

Now's the time for us to say...

Refrain

Happy New Year

Happy New Year

May we all have a vision now and then?

Of a world where every neighbor is a

friend

Happy New Year

Happy New Year May we all have our

hopes, our will to try

If we don't we might as well lay down and die

You and I...

2 Sometimes I see
How the brave new world arrives

And I see how it thrives

In the ashes of our lives

Oh yes, man is a fool

And he thinks he'll be okay

Dragging on, feet of clay

Never knowing he's astray

Keeps on going anyway

Refrain

3 Seems to me now

That the dreams we had before

Are all dead, nothing more

Than confetti on the floor

It's the end of a decade

In another ten years time

Who can say what we'll find

What lies waiting down the line?

In the end of eighty-nine...

Refrain

To learn the linguistic material of the song we can offer the following exercises (Petko, 2011).

I. Practise the pronunciation of the following words and word combinations: champagne, fireworks, here, a vision, every neighbor, now's the time, confetti, never knowing, waiting down the line, nothing more. 
II. Give the Ukrainian equivalents: morning seems so grey, fireworks are through, feeling lost, feeling blue, so unlike yesterday, in the ashes of our lives, lay down, may we all have our hopes, dragging on.

III. Find the English equivalents in the song: загублені, вечірка закінчується, сусід, новий час, на глиняних ногах, десятиліття, прийшов час сказати, воля, надії, попіл нашого життя, плине час, з Новим роком!

IV. Translate into English using the vocabulary of the song: 1. Не треба більше морозива - мені дуже холодно. 2. У мріях Станіслав хоче бути космонавтом. 3. Він не розуміє, що таку роботу складно знайти. 4. Київське «Динамо» знову програло. I ми сидимо біля телевізора розгублені і сумні. 5. Феєрверк на стадіоні закінчується. Я ніколи не забуду цей футбольний матч. 6 . 3 Новим роком! Нехай твої бажання здійсняться. 7. Сьогодні іспит. Ранок здається таким сірим. Оксана сподівається, що все буде добре. 8. Прийшов час сказати, що я тебе зроблю щасливою.

V. Give the Past Tense and Past Participle forms of the following verbs, arrange them in two groups - regular and irregular: to be, to lose, to feel, to seem, to have, to do, to lay down, to see, to live, to know, to go, to die, to say, to wait.

The proposed learning English meets the requirements of training modern specialists. Assimilation of knowledge that allows a future specialist to acquire professional skills is happening through the modeling the subject content of the future profession (Musiichuk, 2009).

Conclusions and perspectives for further research. Thus, the method of learning English through songs by students of "Music" specialty in English classes is efficient and productive, because of enriching the vocabulary, improving the pronunciation and English grammar. Poetic and song material encourages creativity, performing verse translations, composing poetry and songs in native and foreign languages, promotes the memorization of new words due to the rhymed forms as a great way of phonetic training.

The proposed method of learning English through songs provides a positive pedagogical effect and shows the prospects of combining innovation with traditional teaching methods. Therefore, our further task is the development of educational and teaching materials in the proposed aspect and their implementation in higher education institutions.

\section{REFERENCES:}

Haponova, S. (2005). Vykorystannia pisen dlia navchannia inozemnoii movy u pochatkovii shkoli [Using Songs to Teach a Foreign Language in the Primary School]. Inozemni movy, No 3, s. 42-43. [in Ukrainian]

Holubev, A., Smirnova, I. (2003). Pesnia v kurse angliiskogo jazyka: teksty, perevody, uprazhneniia, noty [The Song in the Course of English: Texts, Translations, Exercises and Notes]. Moscow : Akademiia. 304 s. [in Russian]

Zharska, V. (2006). Let's Sing Songs. Anhliiska mova v pochatkovii shkoli, No 1, s. 13-14. [in Ukrainian]

Petko, L. (2011). Robota nad pisneiu v kursi vyvchennia anhliiskoii movy jak odyn iz zasobiv profesiinoii pidghotovky studentiv humanitarnykh spetsialnostei [Working with Song in the Course of Studying English as One of the Means of Training Students of the Humanities]. Inozemni movy, No 1, s. 44-48. [in Ukrainian]

Musiichuk, S. (2009). Psykholohichni i rozvyvalni resursy vykorystannia synerhetychnoho pidkhodu do vykladannia inozemnoii movy u VNZ [Psychological and Developing Resources Using Synergistic Approach in Teaching a Foreign Language at 
Higher Educational Institutions]. Teoretychni pytannia kultury, osvity i vykhovannia, Vyp. 39. Kyiv : KNLU, s. 92-95. [in Ukrainian]

\title{
ВИВЧЕННЯ АНГЛІЙСЬКОЇ МОВИ НА МАТЕРІАЛІ АНГЛОМОВНИХ ПІСЕНЬ ЯК ОДИН ІЗ ІННОВАЦІЙНИХ МЕТОДІВ НАВЧАННЯ
}

\author{
Романюк Світлана \\ кандидат філологічних наук, доцент, \\ доцент кафедри іноземних мов \\ Рівненського державного гуманітарного університету, \\ м. Рівне, Україна \\ ORCID: 0000-0002-9355-4584, \\ e-mail: sve-romanyuk@ukr.net
}

\begin{abstract}
Анотація. Стаття присвячена особливостям впровадження методу вивчення англомовних пісень у викладанні «Англійської мови за професійним спрямуванням» студентам спеціальності «Музичне мистецтво» у вищих навчальних закладах. Автор розглядає сутність і особливості даного інноваційного методу, аналізує його принципи та пріоритети. Зокрема розглядаються етапи роботи над пісенним твором та приклади вправ на засвоєння мовного матеріалу. Обгрунтовується методична доцільність використання методу вивчення англомовних пісень у процесі викладання англійської мови на мистецьких
\end{abstract} спеціальностях.

Останнім часом заклади вищої освіти інтенсифікують процес вивчення іноземних мов шляхом впровадження різноманітних технологій навчання. Метод вивчення англійських пісень студентами спеціальності «Музичне мистецтво» на уроках англійської мови є ефективним і продуктивним, оскільки збагачується словниковий запас, удосконалюється вимова і граматика. Це підвищує ефективність професійної підготовки студентів. Поетичний та пісенний матеріал спонукає до творчості, виконання віршованих перекладів, складання віршів і пісень рідною й іноземною мовами, сприяє запам'ятовуванню нових слів завдяки римованій формі як чудового способу фонетичного тренування. Крім того, така робота викликає інтерес, позитивні емоції, радощі, виступає чинником релаксації, адже протягом заняття важко утримувати увагу студентів, стимулювати їх до активної праці. До того ж розучування пісень на заняттях англійської мови сприяє розвитку здібностей студентів і робить навчання доступним і бажаним.

Запропоноване вивчення англійської мови показує перспективи поєднання інновацій 3 традиційними методами навчання і відповідає вимогам підготовки сучасних фахівців. Асиміляція знань відбувається за допомогою моделювання предметного змісту майбутньої професії, що дозволяє майбутньому фахівцю набувати професійні вміння.

Ключові слова: викладання англійської мови, інноваційний метод, вивчення пісень, мистецькі спеціальності.

Стаття надійшла до редакиії 10.02.2019 p. 